\title{
Validation of a Process-Based Agro-Ecosystem Model (Agro-IBIS) for Maize in Xinjiang, Northwest China
}

\author{
Tureniguli Amuti ${ }^{1}$, Geping Luo ${ }^{2, *}$, Gang Yin ${ }^{3}$, Qi Hu ${ }^{4}$ and E. A. Walter-Shea ${ }^{4}$ \\ 1 School of Geographic Science and Tourism, Xinjiang Normal University, Urumqi 830054, Xinjiang, China; \\ hturangul@xjnu.edu.cn \\ 2 State Key Laboratory of Desert and Oasis Ecology, Xinjiang Institute of Ecology and Geography, \\ Chinese Academy of Sciences, Urumqi 830011, Xinjiang, China \\ 3 Institute of Arid Ecology and Environment, Xinjiang University, Urumqi 830046, Xinjiang, China; \\ chinayg@xju.edu.cn \\ 4 School of Natural Resources, University of Nebraska-Lincoln, Lincoln, NE 68583, USA; \\ qhu2@unl.edu (Q.H.); ewalter-shea1@unl.edu (E.A.W.-S.) \\ * Correspondence: luogp@ms.xjb.ac.cn; Tel.: +86-991-7823127
}

Received: 7 December 2017; Accepted: 27 February 2018; Published: 9 March 2018

\begin{abstract}
Agricultural oasis expansion and intensive management practices have occurred in arid and semiarid regions of China during the last few decades. Accordingly, regional carbon and water budgets have been profoundly impacted by agroecosystems in these regions. Therefore, study on the methods used to accurately estimate energy, water, and carbon exchanges is becoming increasingly important. Process-based models can represent the complex processes between land and atmosphere among agricultural ecosystems. However, before the models can be applied they must be validated under different environmental and climatic conditions. In this study, a process-based agricultural ecosystem model (Agro-IBIS) was validated for maize crops using 3 years of soil and biometric measurements at Wulanwusu agrometeorological site (WAS) located in the Shihezi oasis in Xinjiang, northwest China. The model satisfactorily represented leaf area index (LAI) during the growing season, simulating its peak values within the magnitude of $0-10 \%$. The total biomass carbon was overestimated by $15 \%, 8 \%$, and $16 \%$ in 2004,2005 , and 2006 , respectively. The model satisfactorily simulated the soil temperature $(0-10 \mathrm{~cm})$ and volumetric water content (VWC) $(0-25 \mathrm{~cm})$ of farmland during the growing season. However, it overestimated soil temperature approximately by $4{ }^{\circ} \mathrm{C}$ and VWC by $15-30 \%$ during the winter, coinciding with the period of no vegetation cover in Xinjiang. Overall, the results indicate that the model could represent crop growth, and seems to be applicable in multiple sites in arid oases agroecosystems of Xinjiang. Future application of the model will impose more comprehensive validation using eddy covariance flux data, and consider including dynamics of crop residue and improving characterization of the final stage of leaf development.
\end{abstract}

Keywords: Agro-IBIS; maize; validation; agroecosystem; Xinjiang

\section{Introduction}

The expansion of agriculture and intensification of human activities on a global scale has led to significant changes in the distribution of vegetation, as well as the surface biochemical and biophysical processes [1-8]. Therefore, understanding the extensive changes and management impacts in agricultural ecosystems is significant to examine regional carbon, water, and energy cycles [9-13]. Especially in arid agricultural oases, monitoring and modelling of water and carbon exchanges has become very important for quantitative assessment of these budgets in these regions.

Over the recent decades, researches have been performed on carbon budgets in managed ecosystems at different scales using various methods including process-based models [14-18]. 
However, there is still lack of understanding of the magnitude and spatial-temporal patterns of carbon fluxes due to human-involved processes and less reliable data. Agroecosystems have been reported as a carbon sink, as increased crop yields and intensified management practices have led to accumulations of carbon $[19,20]$. Carbon dynamics in these systems are important for the global terrestrial carbon budget [21,22], but it is challenging to quantify carbon fluxes at a larger scale because of the variability in climate and environmental conditions [23-25]. Numerical models can describe land atmosphere interactions and quantify carbon budgets at multiple scales, from regional to global [26-28]. Until recently, many biosphere models have approximated agricultural ecosystems [29-31]. Some biosphere models have incorporated different agroecosystems into their traditional representation of natural vegetation. There have also been several other ecosystem process models (e.g., CLASS and GLAM) that incorporate agroecosystems into regional climate models [32-36]. Another example is a process-based dynamic agro-ecosystem model, called Agro-IBIS, that is agricultural version of the Integrated Biosphere Simulator (IBIS) [37]. Agro-IBIS can simulate the bio-geophysical processes and agricultural management impacts for specific plant types in natural and managed ecosystems at local, regional, or global scales. The simulation of annual crops (maize, wheat, soybean, sugarcane, etc.) using the Agro-IBIS model has been evaluated in several studies. For example, Kucharik and Twine validated the model using surface flux measurements of carbon, water, and energy at AmeriFlux eddy covariance site in Mead, Nebraska [23]. Twine and Kucharik validated Agro-IBIS by simulating the vegetation phenology in comparison to the satellite information of greenness [38]. Webler et al. evaluated the model by simulating carbon, water, and energy fluxes at an experimental soybean site in southern Brazil [39]. Generally, these models were calibrated for specific sites. However, revalidation of the model is essential before application to different regions due to the variability in soil, climate, and crop conditions. Such validation provides important information about model performance and uncertainty.

The purpose of this study is to validate an agroecosystem model Agro-IBIS against biometric and soil environment observations made over an agro-meteorological site in Xinjiang, northwest China. By comparison of Agro-IBIS results against observations, it is intended to answer how a model calibrated for North American conditions represents the maize crops in northern Xinjiang. Testing the ability of Agro-IBIS model with biophysical crop measurements, soil temperature, and soil moisture observations in this area help examine the performance of the model to simulate surface biophysical processes in arid agricultural oases under various management practices.

\section{Materials and Methods}

\subsection{Study Site}

The field data were collected at the Wulanwusu Agro-meteorological Experiment Station (WAS) $\left(85^{\circ} 49^{\prime} \mathrm{E}, 44^{\circ} 17^{\prime} \mathrm{N}\right)$ in the oasis of Shihezi located in Xinjiang, northwest China. It is characterized by an arid climate with distinct seasons. The mean annual temperature is $7.3^{\circ} \mathrm{C}$, and mean annual precipitation is $220 \mathrm{~mm}$ (averaged over the 1981-2010) with a mean annual pan evaporation of $1664.1 \mathrm{~mm}$. Annual sunshine hours and frost-free period are $2861.2 \mathrm{~h}$ and 170 days, respectively. Gray desert soil is the main soil type with a sandy loam texture, which has an average bulk density of $1.30 \mathrm{~g} / \mathrm{cm}^{3}$. At the study site, irrigated maize was continuously planted on 21 April, 20 April, and 18 April in 2004, 2005, and 2006, respectively. Maize was grown under management of no-tillage in all annually cropped systems.

\subsection{Field Measurements}

The measurement data collected for maize at the site during the growing season from 2004 to 2006 were used to evaluate the performance of Agro-IBIS model. Continuous observations of daily soil temperature at $0-10 \mathrm{~cm}$ and volumetric water content (VWC) at $0-25 \mathrm{~cm}$ soil depth, periodic LAI measurements, aboveground crop biomass, and crop yields were compared with simulated values by 
Agro-IBIS model. A destructive sampling method (every 15-25 days) was used to estimate the values of maize LAI and biomass during the study period.

The total carbon mass (NPP) was calculated using the following equation [40]:

$$
\mathrm{NPP}=\frac{(1-M C) \times Y \times C}{H I \times f_{A G}}
$$

where $M C$ is the grain moisture content during harvest; $Y$ is measured crop yield; $C$ is a factor of carbon conversion of biomass; $\mathrm{HI}$ is the fraction of grain yield in total plant biomass (harvest index); $f_{A G}$ is root to shoot ratio of crops. $H I$ was set to 0.43 . The values of $C, M C$, and $f_{A G}$ were set to 0.45 , 0.11 , and 0.09 , respectively [41].

\subsection{Description of Agro-IBIS Model}

Agro-IBIS is an updated version of the Integrated Biosphere Simulator (IBIS) model, integrating agricultural crops (Figure 1) [42,43]. Currently, it represents 17 plant functional types (PFT), including 12 natural vegetation and 5 crop types (soybean, maize, wheat, sugarcane, and Miscanthus) [44,45]. Agro-IBIS can simulate the biogeophysical processes and agricultural management impacts for specific plant types in natural and managed ecosystems. The model represents the land surface and soil physics (momentum exchanges of energy, water vapor and $\mathrm{CO}_{2}$ among soil, vegetation and atmosphere), plant physiology (photosynthesis, respiration, and conductance), crop phenology (leaf emergence, growth, grain fill, and senescence), carbon balance (NPP, soil respiration, organic matter decomposition), as well as the processes related to agro-ecosystems such as solute transport (nitrogen leaching from fertilizer), and crop management options (cultivar selection, planting and harvest date, fertilizing, and irrigation). Agro-IBIS uses hourly time step to simulate the rapid exchanges of energy, water or $\mathrm{CO}_{2}$ between plant, soil, and atmosphere. The driving data range from meteorological dataset at site level to gridded climate datasets at global scale, so the model can be used to investigate precision agriculture and global climate change impacts on terrestrial ecosystems. Each grid cell includes two canopy layers: upper canopy for forest and lower canopy layer for shrubs, grasses, and crops (lower-level vegetation canopy for corn is used in this study). The model contains three snow layers and eleven soil layers of varying thickness (i.e., 5, 10, 20, 30, 40, 60, 80, 100, 150, $200,250 \mathrm{~cm}$ ) with corresponding physical properties. Richard's equation and Darcy's law are adapted to calculate and model vertical water flux between these soil layers [46]. Agro-IBIS can explicitly represent the temperature and water content of each soil layer, as well as the radiation exchanges between the atmosphere and soil surface. The surface albedo is calculated by the vegetation cover, the surface soil texture class and water content, and the incoming solar radiation. The photosynthesis, stomatal conductance, and respiration of $\mathrm{C} 4$ plants are represented physiologically in mechanistic corn growth model $[47,48]$. To reduce the maximum photosynthetic capacity $\left(\mathrm{V}_{\max }\right)$ of the plant, soil moisture, and leaf-nitrogen stress functions are used. Partitioning of dry matter to carbon pools in plants (leaf, stem, grain, root) and phenological stages of development (planting, leaf emergence, tasseling, and harvesting) during the growing season are dynamic and dependent on base temperature for accumulated growing degree days (GDD). The model can also account for carbon and nitrogen fluxes through vegetation, detritus, and soil organic matter. Daily leaf area expansion is obtained by multiplying total leaf biomass carbon and specific leaf area (SLA) at daily time step. Agro-IBIS simulates evapotranspiration (ET) by the sum of total canopy transpiration and evaporation from soil and plant leaf surfaces. Agro-IBIS does not include groundwater as a lower boundary condition, therefore free drainage is allowed in the model. Canopy and land surface processes of different crop functional types $\left(C_{3}\right.$ and $\left.C_{4}\right)$ are determined by their distinctions in physiology, phenology, and responses to management options and environmental stresses. Agro-IBIS outputs include crop yield, dry matter productivity (leaves, stem, grain, and roots), LAI, evapotranspiration, and carbon as well as energy fluxes. 


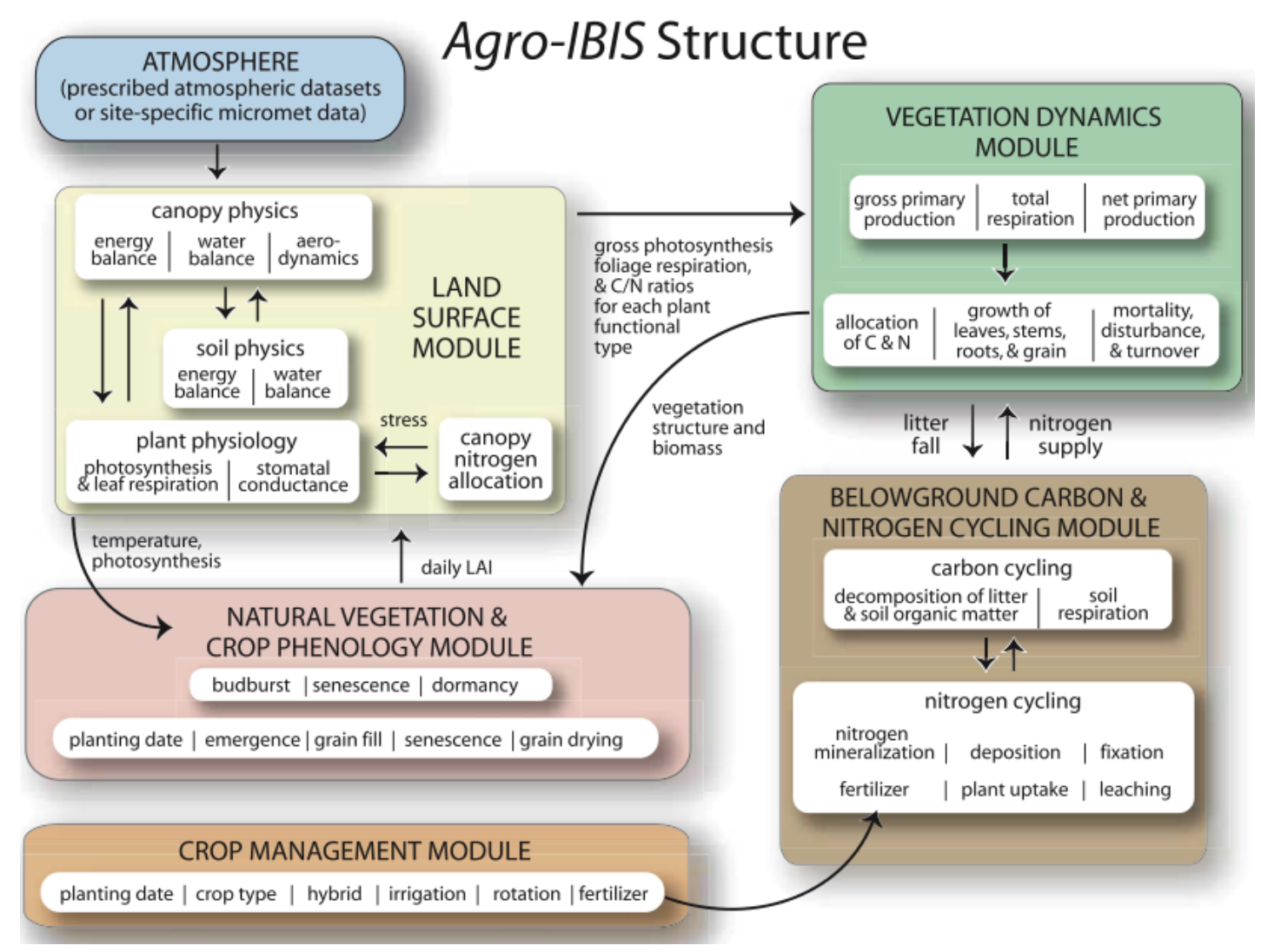

Figure 1. Schematic of Agro-IBIS (adapted from Kucharik et al. [49]).

\subsection{Model Parameters and Input}

The Agro-IBIS model was validated for maize crop using 3 years of observed LAI, leaf and stem carbon, crop yields, and soil temperature and moisture at the WAS site. Hourly meteorological observations (including shortwave radiation, precipitation, air temperature, wind speed and relative humidity) from the WAS site were used to force the model. In model simulations, sandy loam texture was used as dominant soil texture (percentage of sand, silt, and clay) for each soil layer based on local soil measurements and corresponding physical properties at the site. This study used the main parameters of the Agro-IBIS model originally calibrated for North American conditions by Kucharik and Twine [23], and only changed the parameters related to crop phenological stages and management options at the specific site. The level of $\mathrm{CO}_{2}$ in the atmosphere was set to $370 \mathrm{ppm}$. The actual planting date for each year was selected from the site management data. Additionally, GDD 8 was set to 1700 according to the accumulated GDD during the period of planting and harvest dates at the maize site. It was assumed that plant growth was not limited by nitrogen in the simulations. The crop residue management after harvest is not represented in Agro-IBIS, therefore, bare soil conditions exist from harvest through plant emergence. Experimental simulation with Agro-IBIS for the period 2004-2006 was performed for continuous maize at $0.5^{\circ} \times 0.5^{\circ}$ spatial resolution using the parameters listed in Table 1. Irrigated maize crops were assumed to be grown (100\% cover) in model simulations. 
Table 1. Agro-IBIS parameters. LAI: leaf area index. GDD: growing degree days. $\mathrm{V}_{\max }$ : the maximum photosynthetic capacity.

\begin{tabular}{|c|c|}
\hline Main Parameters & Maize (Base $8^{\circ} \mathrm{C}$ ) \\
\hline Maximum LAI $\left(\mathrm{m}^{2} \mathrm{~m}^{-2}\right)$ & 5.2 \\
\hline GDD to leaf emergence & 51.0 \\
\hline Initial fraction $\mathrm{C}$ allocation to leaf & 0.64 \\
\hline Maximum GDD to physiological maturity & 1700 \\
\hline Max GDD past grain fill initiation & 1190 \\
\hline Maximum Harvest Index & 0.65 \\
\hline Initial fraction $\mathrm{C}$ allocation to roots & 0.24 \\
\hline Grain fraction of reproductive $C$ pools & 0.85 \\
\hline End of Season $\mathrm{C}$ allocation to leaf & 0.05 \\
\hline Carbon fraction dry matter (leaf and stem) & 0.43 \\
\hline End of Season C allocation to roots & 0.20 \\
\hline Initial fraction $\mathrm{C}$ allocation to stem & 0.16 \\
\hline End of Season $C$ allocation to stem & 0.10 \\
\hline Carbon fraction in grain & 0.39 \\
\hline $\mathrm{V}_{\max }\left(\mathrm{umol}\left[\mathrm{CO}_{2}\right] \mathrm{m}^{-2} \mathrm{~s}^{-1}\right)$ & 32.5 \\
\hline Field capacity (sandy loam) & 0.027 \\
\hline Wilting point (sandy loam) & 0.095 \\
\hline Campbell's 'b' exponent (sandy loam) & 3.1 \\
\hline saturated hydraulic conductivity ( $\mathrm{m} \mathrm{s}^{-1}$, sandy loam) & $7.1944 \times 10^{-6}$ \\
\hline $\mathrm{C}: \mathrm{N}$ ratio of microbial biomass & 8.0 \\
\hline $\mathrm{C}: \mathrm{N}$ ratio of structural plant (leaf and root) litter & 150.0 \\
\hline $\mathrm{C}: \mathrm{N}$ ratio of metabolic (plant and root) litter & 6.0 \\
\hline C:N ratio of woody biomass components & 250.0 \\
\hline protected biomass fraction of total soil organic carbon & 0.017 \\
\hline
\end{tabular}

The model spin-up run for each year contained 250-year historical datasets of the Climate Research Unit's (CRU) [50] and the National Centers for Environmental Prediction-National Center for Atmospheric Research (NCEP/NCAR) [51] with natural vegetation only from 1751 to 1910 and maize crops from 1911 to 2003 for the grid cell where includes the location of WAS site. This initialization procedure enables the pools of soil organic carbon reach an equilibrium state. Partitioning of carbon in soil was dependent on the carbon accumulated by this additional "spin-up" simulation, which can bring an increase in soil C stock from an initial carbon storage of zero [42].

The monthly climate observations combined with daily reanalysis data at a $0.5^{\circ} \times 0.5^{\circ}$ spatial scale were used to drive the model. These data were obtained by monthly climate anomaly data (1961-1990) from CRU05 dataset (1901-2009) with daily anomalies (1948-2009) from NCEP/NCAR reanalysis data set. The vegetation data was derived from 1-km DISCover land cover dataset and GLC2000 crop fractional coverage data. These daily atmospheric inputs and the CRU monthly climate anomaly were used with combination of statistical weather generator to produce hourly values for all climate variables $[52,53]$. The hourly air temperature and atmospheric humidity are estimated based on Campbell and Norman's method [46]. Within each day, the starting/ending time and duration of a precipitation event are randomly generated. The hourly wind speed is estimated by using the equation from the Environmental Policy Integrated Climate (EPIC) weather generator [54].

\section{Results}

\subsection{Leaf Area Index (LAI)}

LAI is significant for crop simulations, and has direct effects on the fluxes of energy, water, and carbon. LAI observations collected at the WAS site were used to evaluate the ability of Agro-IBIS model to simulate leaf growth in different periods. In Figure 2, the observed and simulated LAI values for maize were compared. These results indicated that the simulated LAI values by Agro-IBIS 
agreed well with measured LAI values. The model captured the rapid rate of LAI increases with slight underestimation from the period after planting to the end of June in 2004 and 2005. However, it overestimated LAI by an average of $27 \%$ in 2006 . The model had difficulty in estimating the LAI from the beginning of August until the end of September across all years, but it performed better for peak LAI, simulating with delay or advance in a time of maximum LAI by a few days and the magnitude within $0-10 \%$. For maize simulation, RMSE (root mean square error) and $r^{2}$ (correlation coefficient) values for overall comparisons of Agro-IBIS against the observed data were $0.98 \mathrm{~m}^{2} \mathrm{~m}^{-2}$ and 0.79 , respectively.
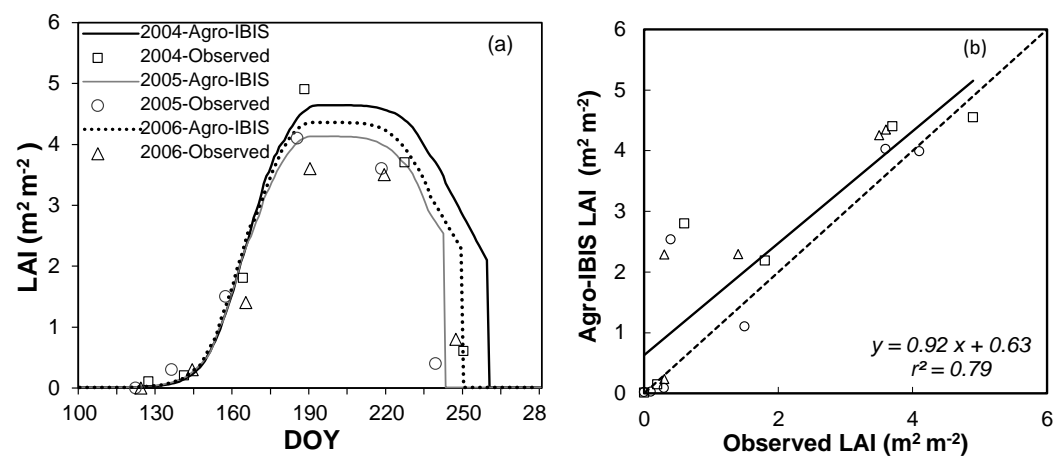

Figure 2. Observed and simulated Leaf Area Index (LAI) for maize (a) and scatter plot comparison (b) from 2004 to 2006 at WAS site. (DOY: day of year. WAS: Wulanwusu Agro-meteorological Station).

\subsection{Crop Biomass}

Biometric measurements of aboveground vegetation biomass (converted to carbon) and simulated biomass carbon were compared to evaluate the performance of Agro-IBIS model. Figure 3 shows the comparison of total simulated aboveground crop biomass (including leaf, stem, and reproductive biomass carbon) and observed values of carbon (calculated by multiplying the dry weight by 0.45 [55]) in each year for maize. The predicted values by the model were found to be acceptable for maize. The biomass carbon values in maize were closely simulated in the growing season. However, the predicted biomass carbon was overestimated by $15 \%, 8 \%$, and $16 \%$ in 2004, 2005, and 2006, respectively. The total simulated aboveground biomass carbon at harvest was $791.2 \mathrm{~g} \mathrm{C} \mathrm{m}^{-2}$ (averaged over the 3 years), among which leaves, stems and reproductive biomass for maize were 118.4, 288.3, $384.5 \mathrm{~g} \mathrm{C} \mathrm{m}^{-2}$, respectively. Further testing for Agro-IBIS was performed by the comparisons of the simulated biomass values against the measured values. The overall $r^{2}$ relevant to all total aboveground crop biomass values was 0.98 , and the RMSE value was $67.2 \mathrm{~g} \mathrm{C} \mathrm{m}^{-2}$.
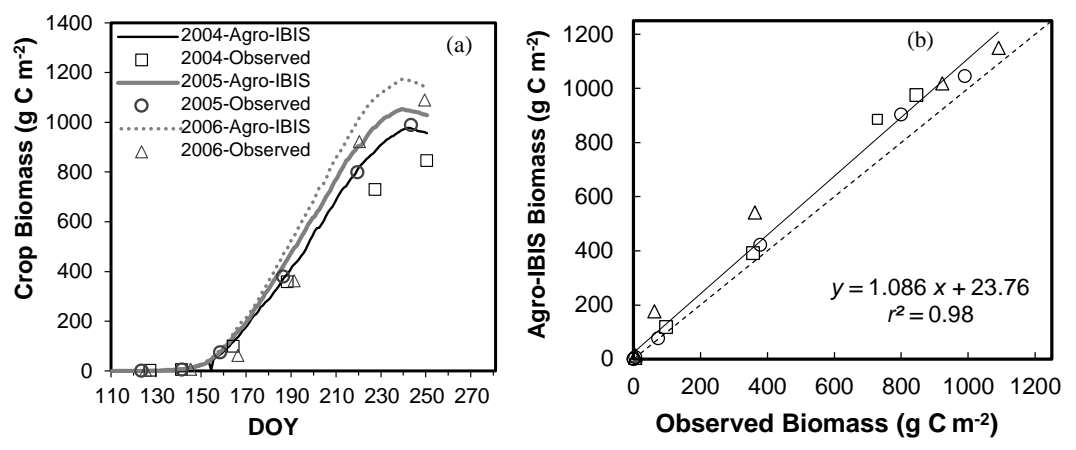

Figure 3. Observed and simulated aboveground biomass carbon for maize (a) and scatter plot comparison (b) from 2004 to 2006 at WAS site. 


\subsection{NPP}

Figure 4 shows the comparison between the simulated NPP by Agro-IBIS and the estimated NPP by observed crop yield based on the method described in Section 2.2. The model-simulated NPP was consistent with the measured NPP in each year, despite the overestimation of observed values by an average of $12.6 \%$ across all years. It indicates that the Agro-IBIS model could correctly represent the inter-annual variability in the measured NPP. The simulated annual NPP averaged 1252, 1098, and $1245 \mathrm{~g} \mathrm{C} \mathrm{m}^{-2}$ year $^{-1}$ for 2004, 2005, and 2006, respectively, while the observed values were 1125, 990, and $1035 \mathrm{~g} \mathrm{C} \mathrm{m}^{-2}$ year $^{-1}$.

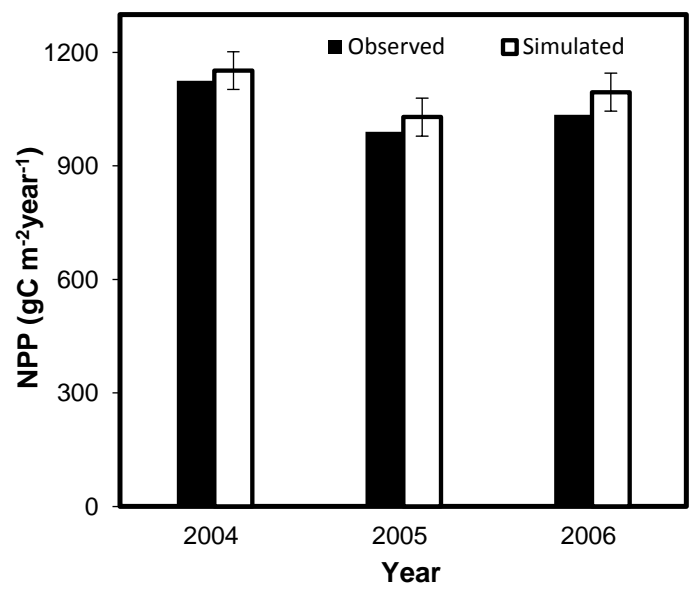

Figure 4. Simulated and observed annual total carbon mass (NPP) for maize at the WAS site.

\subsection{Soil Temperature and Soil Moisture}

The modeled and observed daily average soil temperatures $(0-10 \mathrm{~cm})$ were compared. Their correlation yielded an $r^{2}$ value of 0.96 for maize at the WAS site. The statistical value and the seasonal changes of soil are shown in Figure 5. It indicated that Agro-IBIS could capture seasonal changes in soil temperature. However, the model overestimated soil temperature in each year from early winter until late March (Figure 5). The daily average values of observed soil temperatures were 8.8, 8.8, and $9.5^{\circ} \mathrm{C}$ in 2004, 2005, and 2006, respectively, compared to $12.8,12.9$, and $13.4^{\circ} \mathrm{C}$ for the simulated values. It is revealed from the regression of simulated and measured daily soil temperature (Figure 6) that the model overestimated the soil temperature approximately by $4{ }^{\circ} \mathrm{C}$, even though the overall $r^{2}$ was 0.96 .

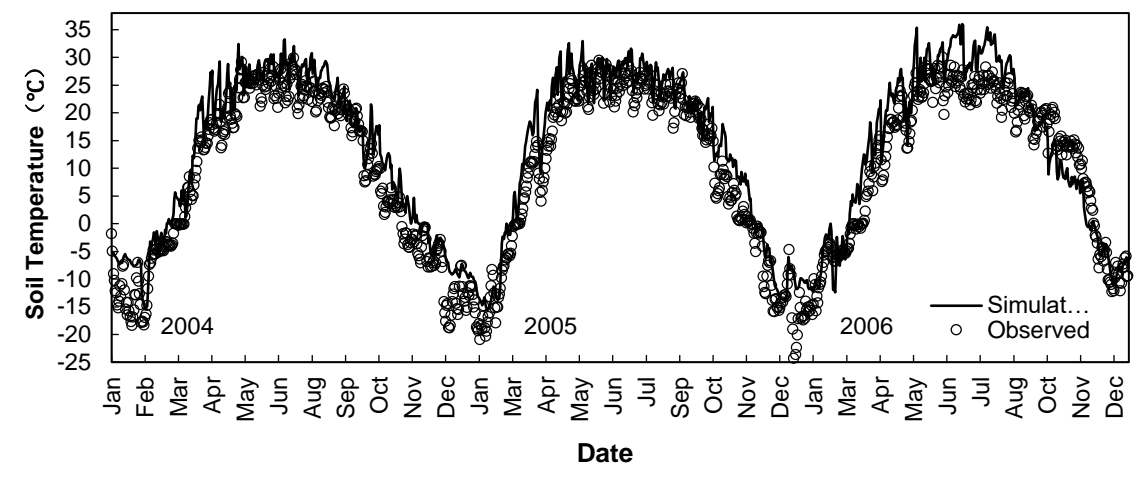

Figure 5. Observed and simulated $0-10 \mathrm{~cm}$ daily average soil temperature at the WAS site. 


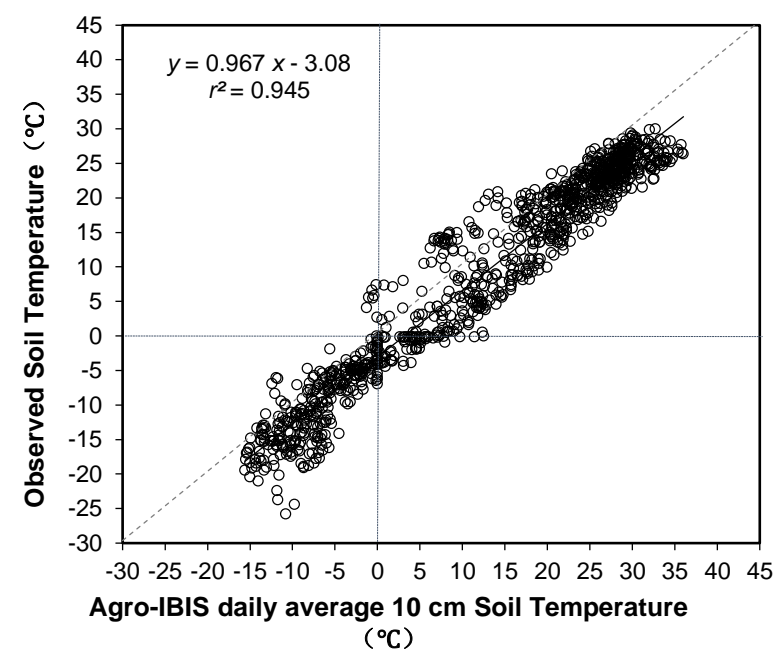

Figure 6. Scatter plot of simulated and observed $0-10 \mathrm{~cm}$ daily average soil temperatures at the WAS site.

The daily average VWC $(0-25 \mathrm{~cm})$ simulated by Agro-IBIS was compared with observed daily average values (Figure 7). Overall, the Agro-IBIS model overestimated VWC by $10 \%$ through all years. Better simulation during the crop growth period, and overestimation of approximately $15-30 \%$ through the early winter (December) to February were observed. The similar simulation errors occurred during the winters of all years at the site. The overall correlation coefficient $\left(r^{2}\right)$ between simulated and observed VWC was 0.29 (Figure 8), and the simulated daily average VWC values over the three years 2004,2005 , and 2006 were $0.32,0.32$, and $0.31 \mathrm{~m}^{3} \mathrm{~m}^{-3}$, respectively, while the measured values were $0.32,0.30$, and $0.28 \mathrm{~m}^{3} \mathrm{~m}^{-3}$.

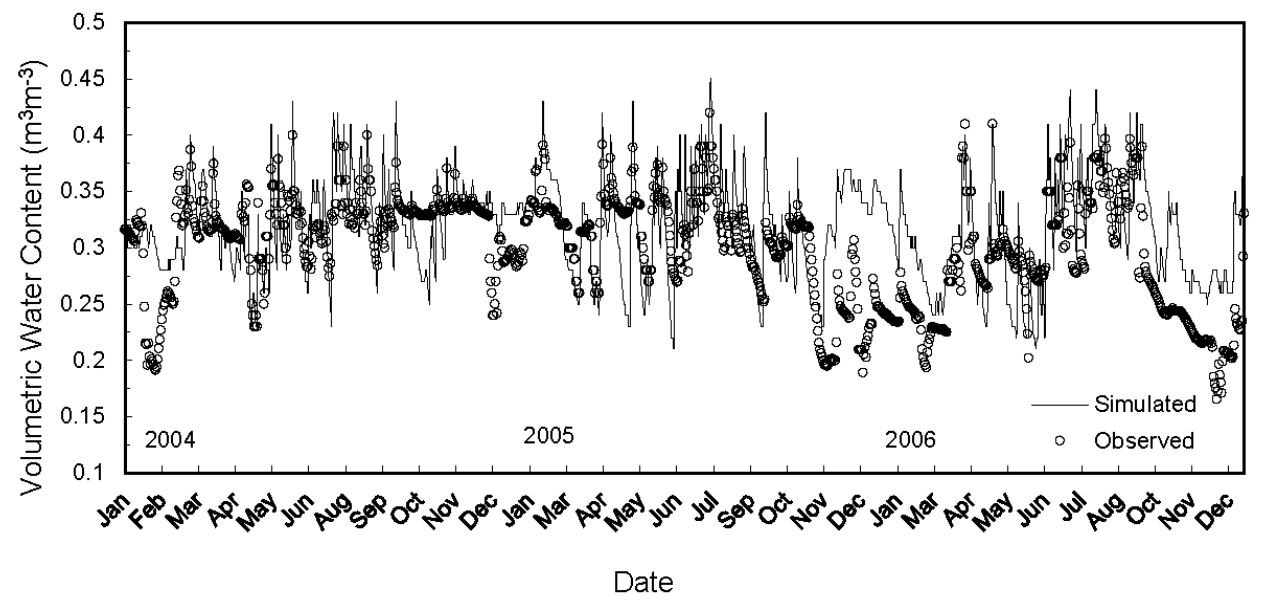

Figure 7. Observed and simulated $0-25 \mathrm{~cm}$ daily average soil volumetric water content at the WAS site. 


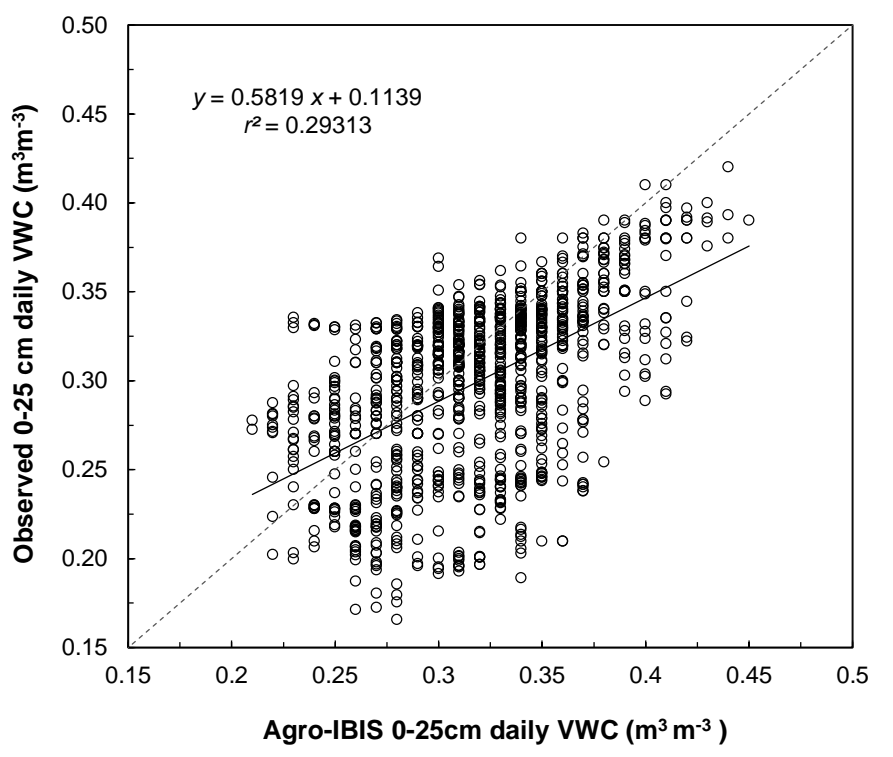

Figure 8. Scatter plot of simulated and observed $0-25 \mathrm{~cm}$ daily average soil volumetric water content at the WAS site.

\section{Discussion}

It was indicated from the evaluation study of Agro-IBIS that the model could represent the maize growth at the WAS site in Xinjiang, northwestern China, despite using the model calibrated for North American conditions. Most of the changes in model parameters were only associated with crop phenological stages and management (i.e., plant height, $\mathrm{V}_{\max }$, the planting and harvest dates, maximum GDD for physiological maturity). Higher $\mathrm{V}_{\max }$ in this parameterization was due to an increased photosynthesis rate in the warm and dry climates where light is intense. The simulated maize LAI closely matched the timing and magnitude during the most of the growing season, despite the poor simulation results within the period of leaf senescence. These errors might be attributed to a bias in systematic parameterization of LAI in cropping systems, which also occurred in previous simulations. Mathematical adjustment to the computation of LAI was suggested recently to obtain a better representation of the grain fill to the physiological maturity period [56].

The biomass accumulation and crop growth rate were well represented by the Agro-IBIS model with slight overestimation across all years. Management practices in arid oasis agriculture such as drip irrigation which contributes to effective use of water (EUW) and crop yield. In fact, a variety of other factors (e.g., fertilizing scheme as well as pests, disease, and nutrient stresses) also affect the $\mathrm{C}$ allocation scheme for individual plant carbon pools [57]. However, these factors cannot be captured by the model. Therefore, the slight deviation between the simulated and observed data might imply the exact conditions in the field.

The model's result in simulating the annual NPP for maize was higher than the observed values. The inadequate modelling of dynamic distribution of carbon assimilates might have resulted in this problem which is mainly caused by the model formulation or parameterizations. The systematic biases that were unrelated to crop type or management practices have been noted previously with IBIS [58].

The soil temperature $(0-10 \mathrm{~cm})$ was closely simulated when crop covered the surface around late May and June with rapidly increasing LAI. However, soil temperatures at near surface $(0-10 \mathrm{~cm})$ were overestimated before growing season in all years. This might be attributed to the absence of vegetative cover. Also, there was overestimation in wintertime soil temperature, which can be improved by representation of surface crop residue. It was reported that crop residues in agroecosystems help conserve higher water content in the soil by attributing to reduced soil temperatures and 
evapotranspiration [59-61]. The consideration of residue cover on the soil surface during the wintertime can lead to a significant positive soil heat flux bias.

Several studies conducted on validations of Agro-IBIS model against observations conducted in natural and managed ecosystems (i.e., agroecosystems) reported an overestimation of soil moisture [39,58]. In this study, soil VWC was overestimated in all years. Despite the overestimation in simulation of soil VWC, Agro-IBIS could capture the daily and seasonal fluctuations in the magnitudes. It can be hypothesized that if residue remained on the soil surface in the continuous irrigated maize field, the irrigated water may have less chance to infiltrate into the soil due to higher interception and re-evaporation. The residue layer covering the soil during wintertime reduces evaporation rate compared to bare soil. The lack of representation of residue cover in Agro-IBIS after harvest most likely resulted in overestimation for the soil VWC in the late fall and winter than any other time. The addition of a surface residue layer (as the process of weathering acts) will likely improve the model performance in future simulations of carbon, water, and energy balance. Such model validations using eddy covariance flux data will further contribute to better simulation results.

\section{Conclusions}

In general, the use of field measurements of biometric variables and soil environment has a significant role in validating the Agro-IBIS model in the oases croplands of Xinjiang. The model, originally calibrated for North American conditions, can persistently represent the crop growth and development of maize at the WAS site in Shihezi oasis. Most of the parameter changes are only associated with the crop phonology and management options. The simulated LAI, total crop biomass, NPP, soil temperature, and soil moisture generally showed good agreement with the measurements, despite the lack of net $\mathrm{CO}_{2}$ flux data for maize crops at the study site. This validation improves our confidence to apply the model at a regional scale in Central Asian agricultural oases in the future. Currently, eddy covariance flux data is available in cotton fields at the WAS site. This will allow us to conduct further comprehensive evaluations of the model's performance with flux measurements by incorporating cotton crops into the Agro-IBIS model. This will substantiate the results of this research and help conduct in-depth assessments of oasis agroecosystems.

Acknowledgments: This study was supported by the National Natural Science Foundation of China (grant No. 41461023, 41671108) and doctoral research funding of Xinjiang Normal University (grant No. XJNUBS1526). The authors express thanks to members of the Agro-IBIS modeling community for providing the assistance with the model simulation process.

Author Contributions: T.A., G.L. and Q.H. conceived and designed the experiments; T.A. conducted the experiments and analyzed the data; G.Y. processed the model input data; T.A. and G.L. wrote the paper; Q.H. and E.A.W.-S. contributed revision and reconstruction of the manuscript.

Conflicts of Interest: The authors declare no conflict of interest.

\section{References}

1. Douglas, E.M.; Niyogi, D.; Frolking, S.; Yeluripati, J.B.; Pielke, R.A.S.; Niyogi, N.; Vörösmarty, C.J.; Mohanty, U.C. Changes in moisture and energy fluxes due to agricultural land use and irrigation in the Indian Monsoon Belt. Geophys. Res. Lett. 2006, 33, 1-5. [CrossRef]

2. Foley, J.A.; DeFries, R.; Asner, G.P.; Barford, C.; Bonan, G.; Carpenter, S.R.; Chapin, F.S.; Coe, M.T.; Daily, G.C.; Gibbs, H.K.; et al. Global consequences of land use. Science 2005, 309, 570-574. [CrossRef] [PubMed]

3. Twine, T.E.; Kucharik, C.J.; Foley, J.A. Effects of land cover change on the energy and water balance of the Mississippi River Basin. J. Hydrometeorol. 2004, 5, 640-655. [CrossRef]

4. Kang, S.; Su, X.; Tong, L.; Zhang, J.; Zhang, L.; Davies, W.J. A warning from an ancient oasis: Intensive human activities are leading to potential ecological and social catastrophe. Int. J. Sustain. Dev. World Ecol. 2008, 15, 440-447. [CrossRef] 
5. Pimentel, D.; Whitecraft, M.; Scott, Z.R.; Zhao, L.X.; Satkiewicz, P.; Scott, T.J.; Phillips, J.; Szimak, D.; Singh, G.; Gonzalez, D.O.; et al. Will limited land, water, and energy control human population numbers in the future? Hum. Ecol. 2010, 38, 599-611. [CrossRef]

6. King, C.; Salem, B. A socio-ecological investigation of options to manage groundwater degradation in the western desert, Egypt. Ambio 2012, 41, 490-503. [CrossRef] [PubMed]

7. Lal, R. Soil erosion impact on agronomic productivity and environment quality. Crit. Rev. Plant Sci. 1998, 17, 319-464. [CrossRef]

8. Zhang, X.Y.; Chen, S.Y.; Sun, H.Y.; Shao, L.W.; Wang, Y.Z. Changes in evapotranspiration over irrigated winter wheat and maize in North China Plain over three decades. Agric. Water Manag. 2011, 98, 1097-1104. [CrossRef]

9. Cirelli, A.F.; Arumí, J.L.; Rivera, D.; Boochs, P.W. Environmental effects of irrigation in arid and semi-arid regions. Chil. J. Agric. Res. 2009, 69, 27-40.

10. Li, Z.Z.; Li, W.D.; Li, W.L. Dry-period irrigation and fertilizer application affect water use and yield of spring wheat in semi-arid regions. Agric. Water Manag. 2004, 65, 133-143. [CrossRef]

11. Hatfield, J.L. Environmental impact of water use in agriculture. Agron. J. 2015, 107, 1554-1556. [CrossRef]

12. Pimentel, D.; Berger, B.; Filiberto, D.; Newton, M.; Wolfe, B.; Karabinakis, E.; Clark, S.; Poon, E.; Abbett, E.; Nandagopal, S. Water resources: Agricultural and environmental issues. BioScience 2004, 54, 909-918. [CrossRef]

13. Zhang, X.; Yang, D.; Xiang, X.; Huang, X. Impact of agricultural development on variation in surface runoff in arid regions: A case of the Aksu River Basin. J. Arid Land 2012, 4, 399-410. [CrossRef]

14. Huang, Y.; Yu, Y.; Zhang, W.; Sun, W.; Liu, S.; Jiang, J.; Wu, W.; Wang, Y.; Yang, Z. Agro-C: A biogeophysical model for simulating the carbon budget of agroecosystems. Agric. For. Meteorol. 2009, 149, 106-129. [CrossRef]

15. Pradeep, W.; Prasanna, H.G.; Xiao, X.; Anup, K.C. Parameterizing ecosystem light use efficiency and water use efficiency to estimate maize gross primary production and evapotranspiration using MODIS EVI. Agric. For. Meteorol. 2016, 222, 87-97.

16. de Noblet-Ducoudre, N.; Gervois, S.; Ciais, P.; Viovy, N.; Brisson, N.; Seguin, B.; Perrier, A. Coupling the soil-vegetation-atmosphere-transfer scheme ORCHIDEE to the agronomy model STICS to study the influence of croplands on the European carbon and water budgets. Agronomie 2004, 24, 1-11. [CrossRef]

17. Lokupitiya, E.; Denning, S.; Paustian, K. Incorporation of crop phenology in Simple Biosphere Model (SiBcrop) to improve land-atmosphere carbon exchanges from croplands. Biogeosciences 2009, 6, 969-986. [CrossRef]

18. Di Vittorio, A.V.; Anderson, R.S.; White, J.D.; Miller, N.L.; Running, S.W. Development and optimization of an Agro-BGC ecosystem model for C4 perennial grasses. Ecol. Model. 2010, 221, 2038-2053. [CrossRef]

19. Chen, Y.; Xiao, C.; Wu, D.; Xia, T.; Chen, Q.; Chen, F.; Yuan, L.; Mi, G. Effects of nitrogen application rate on grain yield and grain nitrogen concentration in two maize hybrids with contrasting nitrogen remobilization efficiency. Eur. J. Agron. 2015, 62, 79-89. [CrossRef]

20. Hollinger, S.E.; Bernacchi, C.J.; Meyers, T.P. Carbon budget of mature no-till ecosystem in north central region of the United States. Agric. For. Meteorol. 2005, 130, 59-69. [CrossRef]

21. Verma, S.B.; Achim, D.; Kenneth, G.C. Annual carbon dioxide exchange in irrigated and rainfed maize based agroecosystems. Agric. For. Meteorol. 2005, 131, 77-96. [CrossRef]

22. Lal, R. Soil carbon sequestration impacts on global climate change and food security. Science 2004, 304, 1623-1627. [CrossRef] [PubMed]

23. Liu, L.L.; Zhu, Y.; Tang, L.; Cao, W.X.; Wang, E.L. Impacts of climate changes, soil nutrients, variety types and management practices on rice yield in East China: A case study in the Tai-Lake region. Field Crop Res. 2013, 149, 40-48. [CrossRef]

24. Bloom, A.A.; Exbrayat, J.F.; Van, I.R.; Feng, L.; Williams, M. The decadal state of the terrestrial carbon cycle: Global retrievals of terrestrial carbon allocation, pools, and residence times. Proc. Natl. Acad. Sci. USA 2016, 113, 172-173. [CrossRef] [PubMed]

25. Yu, G.R.; Zhu, X.J.; Fu, Y.L.; He, H.L.; Wang, Q.F.; Wen, X.F.; Li, X.R. Spatial patterns and climate drivers of carbon fluxes in terrestriall ecosystems of China. Glob. Chang. Biol. 2013, 19, 798-810. [CrossRef] [PubMed]

26. Kucharik, C.J.; Twine, T.E. Residue, respiration, and residuals: Evaluation of a dynamic agroecosystem model using eddy flux measurements and biometric data. Agric. For. Meteorol. 2007, 146, 134-158. [CrossRef] 
27. Suyker, A.E.; Verma, S.B.; Burba, G.G.; Arkebauer, T.J.; Walters, D.T.; Hubbard, K.G. Growing season carbon dioxide exchange in irrigated and rainfed maize. Agric. For. Meteorol. 2004, 124, 1-13. [CrossRef]

28. Zhang, X.S.; Izaurralde, R.C.; Manowitz, D.M.; Xu, M.; Zhao, K.; LeDuc, S.D.; Williams, J.R. Regional scale cropland carbon budgets: Evaluating a geospatial agricultural modeling system using inventory data. Environ. Model. Softw. 2015, 63, 199-216. [CrossRef]

29. Anderson-Teixeira, K.J.; Snyder, P.K.; Twine, T.E.; Cuadra, S.V.; Costa, M.H.; DeLucia, E.H. Climate-regulation services of natural and agricultural ecoregions of the Americas. Nat. Clim. Chang. 2012, 2, 177-181. [CrossRef]

30. Ciais, P.; Gervois, S.; Vuichard, N.; Piao, S.L.; Viovy, N. Effects of land use change and management on the European cropland carbon balance. Glob. Chang. Biol. 2011, 17, 320-338. [CrossRef]

31. Smith, P.; Davies, C.A.; Ogle, S.; Zanchi, G.; Bellarby, J.; Bird, N.; Boddey, R.M.; McNamara, N.P.; Powlson, D.; Cowie, A. Towards an integrated global framework to assess the impacts of land use and management change on soil carbon: Current capability and future vision. Glob. Chang. Biol. 2012, 18, 2089-2101. [CrossRef]

32. Osborne, T.M.; Lawrence, D.M.; Challinor, A.J.; Slingo, J.M.; Wheeler, T.R. Development and assessment of a coupled crop-climate model. Glob. Chang. Biol. 2007, 13, 169-183. [CrossRef]

33. Ramankutty, N.; Delire, C.; Snyder, P. Feedbacks between agriculture and climate: An illustration of the potential unintended consequences of human land use activities. Glob. Planet. Chang. 2006, 54, 79-93. [CrossRef]

34. Gervois, S.; De Noblet-Ducoudré, N.; Viovy, N.; Viocy, N.; Ciais, P. Including croplands in a global biosphere model: Methodology and evaluation at specific sites. Earth Interact. 2004, 8, 1-25. [CrossRef]

35. Challinor, A.J.; Wheeler, T.R.; Craufurd, P.Q.; Slingo, J.M.; Grimes, D.I.F. Design and optimisation of a large-area process based model for annual crops. Agric. For. Meteorol. 2004, 124, 99-120. [CrossRef]

36. Kothavala, Z.; Arain, M.A.; Black, T.A.; Verseghy, D. The simulation of energy, water vapor and carbon dioxide fluxes over common crops by the Canadian Land Surface Scheme (CLASS). Agric. For. Meteorol. 2005, 133, 89-108. [CrossRef]

37. Kucharik, C.J.; Brye, K.R. Integrated BIosphere Simulator (IBIS) yield and nitrate loss predictions for Wisconsin maize receiving varied amounts of Nitrogen fertilizer. J. Environ. Qual. 2003, 32, 247-268. [CrossRef] [PubMed]

38. Twine, T.E.; Kucharik, C.J. Evaluating a terrestrial ecosystem model with satellite information of greenness. J. Geophys. Res. 2008, 113. [CrossRef]

39. Webler, G.; Roberti, D.R.; Cuadra, S.V.; Moreira, V.S.; Costa, M.H. Evaluation of a dynamic Agroecosystem Model (Agro-IBIS) for soybean in Southern Brazil. Earth Interact. 2012, 16, 1-15. [CrossRef]

40. Lobell, D.B.; Hicke, J.A.; Asner, G.P.; Field, C.B.; Tucker, C.J.; Los, S.O. Satellite estimates of productivity and light use efficiency in United States agriculture, 1982-1998. Glob. Chang. Biol. 2002, 8, 1-15. [CrossRef]

41. Bai, J.; Chen, X.; Li, L.; Luo, G.; Yu, Q. Quantifying the contributions of agricultural oasis expansion, management practices and climate change to net primary production and evapotranspiration in croplands in arid northwest China. J. Arid Environ. 2014, 100-101, 31-41. [CrossRef]

42. Foley, J.A.; Prentice, I.C.; Ramankutty, N.; Levis, S.; Pollard, D.; Sitch, S.; Haxeltine, A. An integrated biosphere model of land surface processes, terrestrial carbon balance, and vegetation dynamics. Glob. Biogeochem. Cycles 1996, 10, 603-628. [CrossRef]

43. Kucharik, C.J.; Foley, J.A.; Delire, C.; Fisher, V.A.; Coe, M.T.; Lenters, J.D. Young-Molling, C.; Ramankutty, N.; Norman, J.M.; Gower, S.T. Testing the performance of a dynamic global ecosystem model: Water balance, carbon balance, and vegetation structure. Glob. Biogeochem. Cycles 2000, 14, 795-825. [CrossRef]

44. Vanloocke, A.; Bernacchi, C.J.; Twine, T.E. The impacts of Miscanthus x giganteus production on the Midwest US hydrologic cycle. Glob. Chang. Biol. Bioenergy 2010, 2, 180-191. [CrossRef]

45. Cuadra, S.V.; Costa, M.H.; Kucharik, C.J.; Da Rocha, H.R.; Tatsch, J.D.; Inman-Bamber, G.; Da Rocha, R.P.; Leite, C.C.; Cabral, O.M.R. A biophysical model of Sugarcane growth. Glob. Chang. Biol. Bioenergy 2012, 4, 36-48. [CrossRef]

46. Campbell, G.S.; Norman, J.M. An Introduction to Environmental Biophysics, 2nd ed.; Springer: New York, NY, USA, 1998.

47. Farquhar, G.D.; von Caemmerer, S.; Berry, J.A. A biochemical model of photosynthetic $\mathrm{CO}_{2}$ assimilation in leaves of C3 species. Planta 1980, 149, 78-90. [CrossRef] [PubMed] 
48. Collatz, J.G.; Ball, J.T.; Grivet, C.; Berry, J.A. Physiological and environmental regulation of stomatal conductance, photosynthesis and transpiration: A model that includes a laminar boundary layer. Agric. For. Meteorol. 1991, 53, 107-136. [CrossRef]

49. Kucharik, C.J. Evaluation of a process-based Agro-ecosystem model (Agro-IBIS) across the U.S. corn belt: Simulations of the interannual variability in maize yield. Earth Interact. 2003, 7, 1-33. [CrossRef]

50. Harris, I.; Jones, P.D.; Osborn, T.J.; Lister, D.H. Updated high-resolution grids of monthly climatic observations-The CRU TS3.10 Dataset. Int. J. Climatol. 2014, 34, 623-642. [CrossRef]

51. Kalnay, E.; Kanamitsu, M.; Kistler, R.; Collins, W.; Deaven, D.; Gandin, L.; Iredell, M.; Saha, S.; White, G.; Woollen, J.; et al. The NCEP/NCAR 40-Year Reanalysis Project. Bull. Am. Meteorol. Soc. 1996, 77, 437-471. [CrossRef]

52. Richardson, C.W. Stochastic simulation of daily precipitation, temperature, and solar radiation. Water Resour. Res. 1981, 17, 182-190. [CrossRef]

53. Geng, S.; Penning De Vries, F.W.T.; Supit, I. A simple method for generating daily rainfall data. Agric. For. Meteorol. 1985, 36, 363-376. [CrossRef]

54. Williams, J.R. The EPIC model. In Computer Models of Watershed Hydrology; Singh, V.P., Ed.; Water Resources Publications: Highlands Ranch, CO, USA, 1995.

55. Lieth, H.; Whittaker, R.H. Primary Productivity of the Biosphere; Springer: New York, NY, USA, 1975.

56. Moreira, V.L.; Candido, D.R.; Webler, G.; Diaz, M.; de Gonçalves, L.; Pousa, R.; Degrazia, G. Influence of soil properties in different management systems: Estimating Soybean Water in the AGRO-IBIS Model. Earth Interact. 2017. [CrossRef]

57. Caviglia, O.P.; Melchiori, R.J.M.; Sadras, V.O. Nitrogen utilization efficiency in maize as affected by hybrid and $\mathrm{N}$ rate in late-sown crops. Field Crops Res. 2014, 168, 27-37. [CrossRef]

58. Kucharik, C.J.; Barford, C.C.; Maayar, M.E.; Wofsy, S.C.; Monson, R.; Baldocchi, D.D. A multiyear evaluation of a Dynamic Global Vegetation Model at three AmeriFlux forest sites: Vegetation structure, phenology, soil temperature, and $\mathrm{CO}_{2}$ and $\mathrm{H}_{2} \mathrm{O}$ vapor exchange. Ecol. Model. 2006, 191, 1-31. [CrossRef]

59. Horton, R.; Bristow, K.L.; Kluitenberg, G.J.; Sauer, T.J. Crop residue effects on surface radiation and energy balance-Review. Theor. Appl. Clim. 1996, 54, 27-37. [CrossRef]

60. Sauer, T.J.; Hatfield, J.L.; Prueger, J.H.; Norman, J.M. Surface energy balance of a corn residue-covered field. Agric. For. Meteorol. 1998, 89, 155-168. [CrossRef]

61. Steiner, J.L.; Schomberg, H.H. Impacts of crop residue at the earth-atmosphere interface: Introduction. Theor. Appl. Clim. 1996, 54, 1-4. [CrossRef] 